Article

\title{
Comparison of Ferry Boat and Highway Bridge Energy Use
}

\author{
Wayne D. Cottrell \\ Department of Civil Engineering and Construction Engineering Management, California State \\ University, Long Beach, 1250 Bellflower Boulevard, Long Beach, CA 90840, USA; \\ E-Mail: waynecottrell@advancedtransit.net; Tel.: +1-562-985-5118
}

Received: 18 November 2010; in revised form: 15 January 2011 / Accepted: 20 January 2011 / Published: 27 January 2011

\begin{abstract}
Passenger ferries serve a variety of transport needs in the U.S., such as providing vital links across bodies of water, and supplementing highway bridges. In some cases in which there is a ferry connection but no bridge, a bridge would be impractical; in other cases, a bridge might be feasible. The paper compares the energy consumption of ferries and motor vehicles on bridges, to determine which link is more fuel efficient. One finding is that limited data are available on ferry boat fuel consumption: despite there being 208 ferry boat operators in the U.S. as of 2008, only eight were providing energy use data to the National Transit Database. Examinations of three of the systems found that the passenger-MPG of the ferries ranged from 2.61 to 14.00 (1.11 to $5.95 \mathrm{~km} / \mathrm{L})$, while that of the motor vehicles on adjacent highway bridge connections ranged from 25.34 to 32.45 (10.77 to $13.79 \mathrm{~km} / \mathrm{L})$. Data from the eight systems are used to develop a ferry MPG model. The model is used to show that the Ryer Island and Charles Hall Ferries are less fuel efficient than hypothetical bridges in those locations. The fuel efficiencies and consumptions of the ferries would equal those of motor vehicles on the bridges, however, if smaller vessels were used, and if the frequency of service was reduced.
\end{abstract}

Keywords: fuel efficiency; fuel consumption; ferry boats; highway vehicles; diesel fuel

\section{Introduction}

There were 208 passenger ferry boat transportation operators in the U.S. as of 2008, providing services on over 300 links in 37 States. Route lengths ranged from just $0.064 \mathrm{~km}$, at Mammoth Cave National Park in Kentucky, to over 950 km, along the Aleutian Islands in Alaska. In many settings, ferry boats provided the only or primary means of access across a body of water. In other settings, 
ferry boats supplemented highway bridges. In still other settings, ferries provided a more direct connection between two points, separated by a body of water, than a longer highway route. In California, for example, the Blue and Gold Fleet and Golden Gate Ferries supplement a collection of highway bridges in spanning the San Francisco Bay. Along the Sacramento River, however, three different ferry boat links provide river crossings where there are no bridge connections. In this paper, ferry boats and highway bridges are compared in terms of energy consumption. The energy consumed by ferry boats in moving a certain number of persons across a body of water is compared with the energy consumed by motor vehicles in moving persons over a bridge that crosses the same body of water. The findings can be used to answer the following: When is a ferry boat system more fuel efficient than a highway bridge? Or, to rephrase, would there be any energy savings in having a bridge, rather than a ferry boat link? The general approach is to examine the empirical data on ferry boats, bridges, and energy use firstly, and then to, secondly, generalize the results. The paper concentrates on data from the U.S. The analysis ignores the costs of bridge construction and maintenance, as well as the costs of ferry boat purchase and upkeep.

\section{Literature Review}

While the literature on highway fuel consumption is abundant, studies on ferry boat fuel use are scarce. Bradley and Assoc. [1] calculated an average ferry boat diesel fuel consumption of 12.6 passenger-miles per gallon (passenger-MPG), based on data from the National Transit Database (which is discussed further below). This compared to national averages of 27.7 passenger-MPG for a single-occupant vehicle, 32.5 passenger-MPG for a city transit bus, and 55.4 passenger-MPG for a two-person carpool in 2007. Automobile fuel consumption rates were based on a U.S. fleet economy average of 22.7 MPG. Perry [2] compared ferry services between Dorena, Missouri and Reelfoot Lake, Tennessee, and ferry services between Dorena and Fulton, Kentucky, with driving between the two city pairs. He found that, in both cases, the driving trip was three times as long by distance as the ferry trip. The cost of fuel was estimated to be $\$ 10$ to $\$ 15$ greater per person-trip by motor vehicle than by ferry, including the impacts of the longer distances. The Environmental Protection Agency (EPA) proposed the commercial marine vessels fuel consumption model shown in Equation (1):

$$
\mathrm{FC}=(14.1205 / \mathrm{FL})+205.7169
$$

where:

$\mathrm{FC}=$ fuel consumption in $\mathrm{gm} / \mathrm{kW}$-hr;

$\mathrm{FL}=$ fractional load;

$=$ actual engine output/relative engine output.

The equation was developed from 291 tests made on marine vessel engine sizes ranging in load (i.e., fractional load) from $0 \%$ (idling) to $100 \%$ (full throttle). Sixteen of the engines had power output ratings of $10,000 \mathrm{~kW}$ or greater (i.e., much higher than that of the largest, fastest ferry boats) [3]. Further discussion of the EPA equation is found in the concluding section of this paper.

Studies on highway fuel consumption have tended to be either raw data summaries, or analyses of specific aspects of fuel use. Regarding the former, the EPA reported gasoline consumption rates of 0.0417 gallons/mi for passenger cars, and 0.0578 gallons/mi for light-duty trucks, for the year 2005 
U.S. motor vehicle fleet, using factors in the MOBILE6.2 model [4]. The model assumed a properly-maintained vehicle and warm ambient air temperature $\left(72-92^{\circ} \mathrm{F}\right)$. Regarding the latter, there have been studies of fuel economy and how it is affected by tires, gasoline additives, temperature, cold starts, acceleration rates, and other factors (e.g., [5]). Average fuel economy values do not necessarily capture the wide variation possible.

Despite the extensive availability of fuel consumption data, and the large number of reports and studies, there have been few comparisons of motor vehicles and ferry boats in terms of energy use. Bradley, reported above, developed passenger-MPG rates for the two modes, but did not determine the total amount of fuel consumed per person over a set trip or distance. Perry developed energy costs per person-trip for ferries and motor vehicles, but did not compute fuel consumption totals; further his results were biased toward ferries, mainly because the motor vehicle trip was much longer. Also, none of the studies considered traffic volumes or travel demands. This paper attempts to fill in some of these gaps by comparing ferry and motor vehicle fuel use over equivalent travel distances, while taking into account the travel demands.

\section{Ferry Operations in the U.S.}

There were 208 passenger ferry boat transportation operators in the U.S. as of 2008, providing services on over 300 links in 37 States. The National Census of Ferry Operators [6] indicated that there were 681 vessels in use in the U.S. in 2008. The majority of them (88.8\%) operated on diesel fuel. Of the others, 1.5\% used gasoline, 1.2\% used biodiesel, 0.6\% used B20 (20\% biodiesel, 80\% diesel), $0.4 \%$ were electric, and $2.3 \%$ were unpowered (i.e., barges). The remaining $5.2 \%$ included one vessel operating on compressed natural gas, one cable-powered, one coal-powered, one electric-powered with solar panels, one hand-powered, and several "not reported." Forty-six of the operators were operating one or more non-diesel-powered vessels, including 21 operators who were not operating any diesel vessels.

Ferry boat fuel consumption data are not widely available. For example, of the 208 U.S. operators, only eight provided fuel use data to the National Transit Database [7] in 2008. All of these operators were using diesel-fuel vessels; one was also using biodiesel-fueled vessels, while one was also using a gasoline-powered vessel. A total of 98 ferry boats were being used by these operators, representing $14 \%$ of all vessels in use in 2008 . Fuel consumption data were provided by operator, rather than by boat, making it a challenge to compare the energy use of small and large vessels. Fuel efficiency ranged from 0.05 MPG $(0.023 \mathrm{~km} / \mathrm{L})$ for the Washington State Ferries (28 vessels) to $0.46 \mathrm{MPG}$ $(0.195 \mathrm{~km} / \mathrm{L})$ for the Savannah Belle Ferries of the Chatham Area Transit Authority (3 vessels). The wide variation in efficiency was related to differing vessel characteristics, the most notable being boat size, as well as varying conditions (water current speed and wind). Operating speed was also a factor. Regarding boat size, the average capacity of the Savannah Belle Ferries was 117 passengers, while that of the Washington State Ferries was 1330 passengers. The average capacity of the New York City DOT's Staten Island ferries was 3400 passengers. The data are summarized in Table 1.

Table 1 also shows the passenger-MPG of the eight systems, which is perhaps a better measure of ferry boat energy use efficiency than MPG. The values ranged from 2.61 (1.11 passenger-km/L) for the Crescent City Connection to 49.00 (20.84 passenger-km/L) for the Staten Island Ferry, which 
operated the largest boats. The typical operating speeds of the eight systems ranged from $7 \mathrm{mph}$ $(4.3 \mathrm{~km} / \mathrm{h})$, for the Crescent City Connection and Savannah Belle Ferries, to $34 \mathrm{mph}(21 \mathrm{~km} / \mathrm{h})$ for two of the Golden Gate Ferry boats.

Table 1. Year 2008 Diesel Fuel Consumption by Selected U.S. Ferry Boat Operators ${ }^{1}$.

\begin{tabular}{llcccc}
\hline \multicolumn{1}{c}{ Operator } & \multicolumn{1}{c}{ Location } & Vessels & $\begin{array}{c}\text { Average } \\
\text { Passenger } \\
\text { Capacity }\end{array}$ & MPG & $\begin{array}{c}\text { Passenger } \\
\text { MPG }\end{array}$ \\
\hline $\begin{array}{l}\text { Casco Bay Island } \\
\text { Transit }\end{array}$ & Portland, Maine & 5 & 369.60 & 0.28 & 7.28 \\
\hline $\begin{array}{l}\text { Crescent City } \\
\text { Connection }\end{array}$ & $\begin{array}{l}\text { New Orleans, } \\
\text { Louisiana }\end{array}$ & 6 & 706.67 & 0.08 & 2.61 \\
\hline $\begin{array}{l}\text { Golden Gate Ferries } \\
\text { Can Francisco, }\end{array}$ & 5 & 597.00 & 0.12 & 14.00 \\
\hline $\begin{array}{l}\text { Maritime } \\
\text { Transportation } \\
\text { Authority }\end{array}$ & $\begin{array}{l}\text { San Juan, Puerto } \\
\text { Rico }\end{array}$ & 7 & 149.00 & 0.13 & 10.17 \\
\hline $\begin{array}{l}\text { New York City } \\
\text { DOT }\end{array}$ & $\begin{array}{l}\text { New York City, } \\
\text { New York }\end{array}$ & 10 & 3400.90 & 0.09 & 49.00 \\
\hline $\begin{array}{l}\text { Port Imperial Ferry } \\
\text { (NY Waterway) }\end{array}$ & $\begin{array}{l}\text { New York City, } \\
\text { New York }\end{array}$ & 32 & 227.91 & 0.23 & 9.75 \\
\hline $\begin{array}{l}\text { Savannah Belle } \\
\text { Ferries }\end{array}$ & $\begin{array}{l}\text { Savannah, } \\
\text { Georgia }\end{array}$ & 3 & 116.67 & 0.46 & 4.80 \\
\hline $\begin{array}{l}\text { Washington State } \\
\text { Ferries }\end{array}$ & $\begin{array}{l}\text { Seattle, } \\
\text { Washington }\end{array}$ & 28 & 1330.36 & 0.05 & 10.55 \\
\hline $\begin{array}{l}1 \\
\text { The operators listed were the only ones to submit fuel consumption data to the National Transit } \\
\text { Database in 2008. NOTE: To convert MPG to km/L, multiply by 0.425. }\end{array}$ & &
\end{tabular}

\section{Selection of Ferry Systems for Further Study}

The routes traveled by each of the ferry systems were compared with parallel (if any) highway routes. Most of the ferry systems featured multiple routes. Five of the eight systems had routes with one or more highway alternatives. There are no highway alternatives to the routes served by Casco Bay Island Transit in Maine, since none of the islands is connected to the mainline by road. As for the Washington State Ferries, the highway alternatives involve extended driving distances, as needed to circumnavigate Puget Sound. The Maritime Transportation Authority offered a ferry link between San Juan and Cataña, Puerto Rico, across the Bahia de San Juan. Although the Bahia can be circumnavigated by road, the driving distance was considered to be too lengthy - in addition to surface street congestion-for a suitable comparison with the direct ferry link. The Port Imperial Ferry connected New Jersey with Manhattan across the Hudson River, using three Manhattan terminals, via several routes. The Staten Island Ferry (operated by the New York City DOT) connected Staten Island with Manhattan across Upper New York Bay. Both of the New York City-oriented ferry systems were excluded from the study because of the numerous travel alternatives available. For example, between New Jersey and Manhattan, in addition to three different ferry routes, there were three tunnel or bridge 
connections, Port Authority of New York and New Jersey rail transit, and a number of bus lines. The remaining ferry systems (Crescent City Connection, Golden Gate Ferries, and Savannah Belle Ferries), their routes and highway alternatives, were examined in detail.

The methodology involved computing and comparing the passenger MPG for each water crossing mode, including passenger cars, bus transit (if any), and ferries. The number of passenger cars was obtained from traffic volume data from State Department of Transportation publications which, when multiplied by the crossing length and an average vehicle occupancy rate, produced passenger-miles. For bus transit and ferries, passenger mileage and fuel consumption data were obtained from the National Transit Database. Fuel consumption for passenger cars was determined by multiplying the crossing length by the inverse of the average fuel efficiency rates for cars and light-duty trucks (i.e., pickups, sport-utility vehicles and vans). As another measure of performance, the BTU per passenger-mile was also computed, by converting gasoline or diesel fuel consumption into BTU.

\section{Case Study: Golden Gate Ferries}

Golden Gate Ferries, operated by the Golden Gate Bridge, Highway and Transportation District (GGBHTD), was providing two regular links between San Francisco and Marin County to the north. One link was to Sausalito (5.5 mi or $8.85 \mathrm{~km}$ trip length), and the other was to Larkspur (11.25 mi or $18.1 \mathrm{~km})$. The ferries carried 1,979,843 passengers in 2008, accumulating 22,035,800 passenger-mi $(35,463,250$ passenger-km) [8]. The GGBHTD also operated the Golden Gate Bridge, which is the sole highway connection between San Francisco and Marin County, and Golden Gate Transit, which provides bus service in Marin County, and to San Francisco. The Golden Gate Bridge carried a total of 39,315,506 vehicle crossings in 2008 [9]. Given the bridge's 1.65-mi (2.65-km) length, the annual vehicle-mi were 64,870,584 (104,399,280 vehicle-km). Golden Gate Transit buses carried $2,700,000$ patrons across the bridge in 2008. There were four routes that used the bridge to travel between Marin County and San Francisco, accumulating a total of 4,455,000 bus passenger-mi $(7,169,641$ passenger-km) in 2008 [10]. There were a total of 41,044 one-way bus crossings of the bridge, covering 67,723 vehicle-mi (108,989 vehicle-km) in 2008. The Golden Gate Bridge trips represented 1.28\% of Golden Gate Transit's revenue vehicle-mi in 2008 [11]. The bridge and bus statistics do not consider actual trip lengths; that is, only the bridge segment is considered.

Using the national average passenger car fuel efficiency rate of 22.7 MPG in 2007 (the most recent year of data available), the national average light trucks fuel efficiency rate of 18.0 MPG, and the year 2008 California motor vehicle registrations distribution of $62.5 \%$ passenger cars and $37.5 \%$ light trucks [12], then the estimated average fuel efficiency of motor vehicles crossing the Golden Gate Bridge (excluding buses and trucks) was 20.81 MPG (8.84 km/L). Heavy trucks represented 1.33\% of all motor vehicles on the Golden Gate Bridge in 2008; although the national average fuel efficiency rate for combination trucks was just 5.4 MPG (2.30 km/L), truck fuel consumption was not considered; i.e., the study was limited to passenger transportation.

Combining the preceding statistics, 38,751,566 motor vehicles and 41,044 buses burned 3,072,565 gal $(11,630,923 \mathrm{~L})$ of gasoline and $1.28 \%$ of $1,601,900$ gal, or 20,504 gal $(77,617 \mathrm{~L})$ of diesel fuel, respectively, in crossing the Golden Gate Bridge in 2008. These values compared to the 1,574,000 gal (5,958,238 L) of diesel fuel consumed by Golden Gate Ferries in 2008. (Transit fuel consumption data 
were obtained from the National Transit Database). As shown in Table 1, the passenger MPG of the ferries was $14.00(5.95 \mathrm{~km} / \mathrm{L})$. The Golden Gate Transit bus passenger-MPG across the bridge was 217.27 (92.34 km/L). Assuming an average car occupancy of 1.2, the car and light trucks driver-passenger MPG across the bridge was $25.34(10.77 \mathrm{~km} / \mathrm{L})$. (The car occupancy rate was estimated from a San Francisco Bay Area rate of 1.33 for all trips, as determined in a 1990 regional household travel survey. Since then, it has been observed that the vehicle occupancy rate in the Bay Area has decreased, although actual data were not available [13,14]). Thus, the passenger fuel efficiency of the ferries was only $6 \%$ of that of the buses. The ferries were not as fuel efficient as the cars and light trucks; the passenger fuel efficiency of the ferries would be roughly equivalent to that of the highway vehicles, however, if the ferry passenger demand were nearly doubled. If all of Golden Gate Transit's 2.7 million San Francisco-bound patrons switched to the ferry boats, for example, then the passenger-mileage on the Golden Gate Ferries would increase to 52,087,000 $(83,826,060$ passenger-km). Presuming that the existing ferry service could accommodate the increased patronage, then the passenger MPG would increase to $33.09(14.06 \mathrm{~km} / \mathrm{L})$. The data are summarized in Table 2. Photos of the bridge and a typical ferry are shown in Figure 1.

Table 2. Year 2008 Golden Gate Ferry and Golden Gate Bridge Statistics ${ }^{1}$.

\begin{tabular}{lccccc}
\hline \multicolumn{1}{c}{ Mode } & Route & Passenger-Mi & $\begin{array}{c}\text { Fuel Consumed } \\
\text { (gal) }\end{array}$ & $\begin{array}{c}\text { Passenger } \\
\text { MPG }\end{array}$ & BTU/Pass-Mi $^{3}$ \\
\hline $\begin{array}{l}\text { Golden Gate } \\
\text { Ferries }\end{array}$ & NA & $22,085,800$ & $1,574,000$ & 14.00 & 9229.1 \\
$\begin{array}{l}\text { Golden Gate } \\
\text { Bridge }\end{array}$ & $1.65 \mathrm{mi}$ & $76,728,1004$ & $3,072,565$ & 25.34 & 4565.1 \\
$\begin{array}{l}\text { Golden Gate } \\
\text { Transit }\end{array}$ & $1.65 \mathrm{mi}$ & $4,455,000$ & 20,504 & 217.27 & 596.0 \\
\hline
\end{tabular}

${ }^{1}$ Serving San Francisco and Marin County, California; ${ }^{2}$ Ferries and transit: diesel; bridge (motor vehicles): gasoline; ${ }^{3}$ Gasoline: 1 gal $=114,000 \mathrm{BTU}$; diesel: 1 gal $=129,500 \mathrm{BTU} ;{ }^{4}$ Including passenger cars and light trucks; average vehicle occupancy of 1.2 assumed.

Figure 1. Golden Gate Bridge and Golden Gate Ferry $[15,16]$.

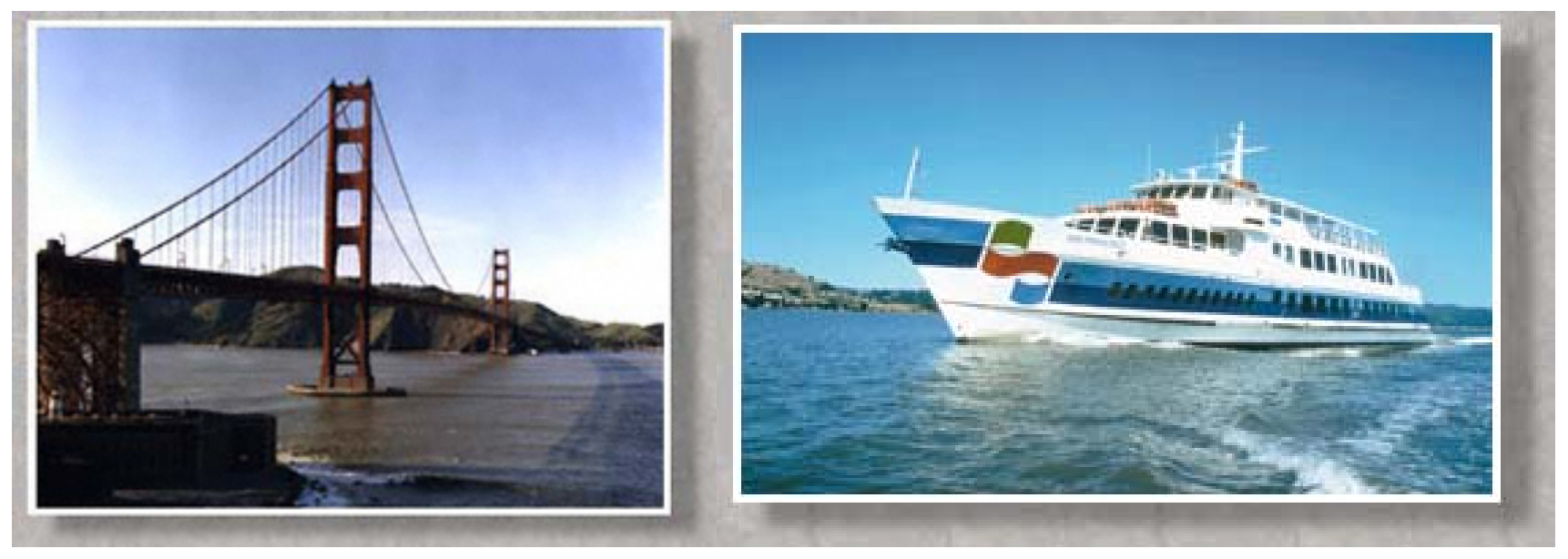




\section{Case Study: Savannah Belle Ferries}

The Savannah Belle Ferries of the Chatham Area Transit Authority in Savannah, Georgia were operating two links across the Savannah Front River, between the Savannah waterfront and Hutchinson Island. The route lengths were $0.44 \mathrm{mi}(0.71 \mathrm{~km})$ and $0.33 \mathrm{mi}(0.53 \mathrm{~km})$. Highway access to the island, and beyond (northward into South Carolina) is provided by the Talmadge Memorial Bridge (US 17; also SR 404). Bridge motorists have the option of exiting onto Hutchinson Island, or continuing across the Savannah Back River, into South Carolina. Thus, only a proportion of bridge traffic is oriented toward the island. The ferries carried 523,456 passengers in 2008, accumulating 185,300 passenger-mi (282,212 passenger-km). The Talmadge Bridge featured an annual average daily traffic volume (AADT) of 16,020 in 2008 across the Front River, and 13,520 across the Back River [17], suggesting a daily loss of 2500 vehicles to the island. (Hutchinson Island features the Savannah Trade and International Convention Center, a resort, an automobile race track, and other recreational and visitor-oriented land uses). The annual vehicular total was 912,500. Given a bridge length of $1.2 \mathrm{mi}(1.95 \mathrm{~km})$ between Savannah and Hutchinson Island, the annual vehicle-mi were 1,095,000 (1,762,235 vehicle-km). There was no local bus transit service to the island.

The Savannah Belle Ferries consumed 38,600 gal of diesel fuel in 2008. Using Georgia’s year 2008 motor vehicle registrations distribution of $52 \%$ passenger cars and $48 \%$ light trucks, and the rates discussed above, the estimated average fuel efficiency for motor vehicles crossing the bridge was 20.34 MPG (8.64 km/L). The 912,500 annual motor vehicles therefore, burned 53,835 gal of gasoline in 2008 in crossing Talmadge Bridge. Note that these numbers do not include charter and subscription buses, for which there were no data. Also, local motor vehicle occupancy statistics were not available for this study, but an occupancy rate of 1.5 persons per vehicle was obtained from data collected near the Las Vegas, Nevada convention center in 2003 [18]. This rate was assumed to be applicable to Hutchinson Island traffic. Thus, a total of 1,642,500 passenger-mi (2,643,353 passenger-km) were accumulated on Talmadge Bridge by Hutchinson Island-bound vehicles. A photo of the bridge is shown in Figure 2.

Overall, motor vehicles on Talmadge Bridge that were bound for Hutchinson Island consumed 53,835 gal (203,787 L) of gasoline in 2008, while the Savannah Belle Ferries consumed 38,600 gal $(146,116 \mathrm{~L})$ of diesel fuel. The passenger-MPG of the ferries was 4.80 , while that of the Talmadge Bridge vehicles was 30.51. Similarly, the BTU consumed per passenger-mi for the ferries, at 26,976.3, was much greater than the 3,736.5 BTU per passenger-mi consumed on Talmadge Bridge. Motor vehicles, therefore, were much more fuel efficient on a per passenger-mi basis than the ferry boats. A substantial increase in ferry boat patronage would be needed to improve the fuel efficiency. The data are summarized in Table 3. One of the Savannah Belle ferries is shown in Figure 3.

Table 3. Year 2008 Savannah Belle Ferry and Talmadge Bridge Statistics ${ }^{1}$.

\begin{tabular}{lccccc}
\hline \multicolumn{1}{c}{ Mode } & Route & Passenger-Mi & $\begin{array}{c}\text { Fuel Consumed } \\
\text { (gal) }\end{array}$ & $\begin{array}{c}\text { Passenger } \\
\text { MPG }\end{array}$ & BTU/Pass-Mi \\
\hline $\begin{array}{l}\text { Savannah Belle } \\
\text { Talmadge }\end{array}$ & $0.44 \mathrm{mi}$ & 185,300 & 38,600 & 4.80 & $26,976.3$ \\
Bridge & $1.20 \mathrm{mi}$ & $1,642,500$ & 53,835 & 30.51 & 3736.5 \\
\hline
\end{tabular}

\footnotetext{
${ }^{1}$ Serving Savannah, Georgia; ${ }^{2}$ Ferries: diesel; bridge (motor vehicles): gasoline.
} 


\section{Case Study: Crescent City Connection}

The Crescent City Connection, a division of the Louisiana DOT, operates Mississippi River crossings, including bridges and ferries, in the Jefferson, Orleans, and St. Bernard Parishes. Orleans Parish includes the city of New Orleans. Three ferry boat links connect New Orleans and Chalmette north of the river (at three different terminals) with Algiers and Old Aurora (neighborhoods of New Orleans), and Gretna, all south of the river. Twin bridges-Greater New Orleans Bridge (one-way eastbound, to south side of river) and Greater New Orleans Bridge \#2 (one-way westbound, with U.S. $\$ 1$ cash toll) — cross the river approximately central to the three ferry links, along US 90-Z. The ferry boats accumulated 982,000 passenger-mi (1,580,400 passenger-km) in 2008.

Figure 2. Talmadge Bridge [19].

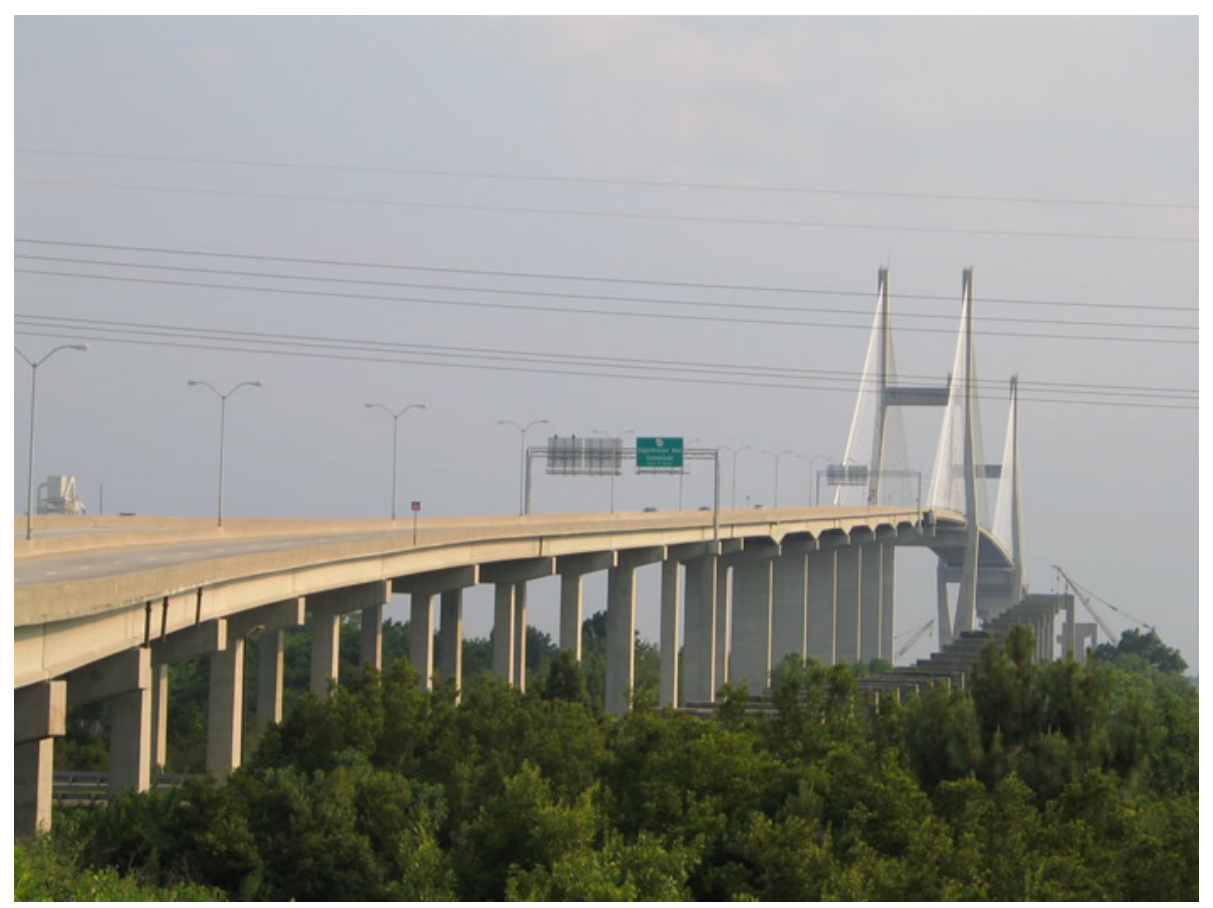

Figure 3. Savannah Belle Ferry (Juliette Gordon Low boat) [20].

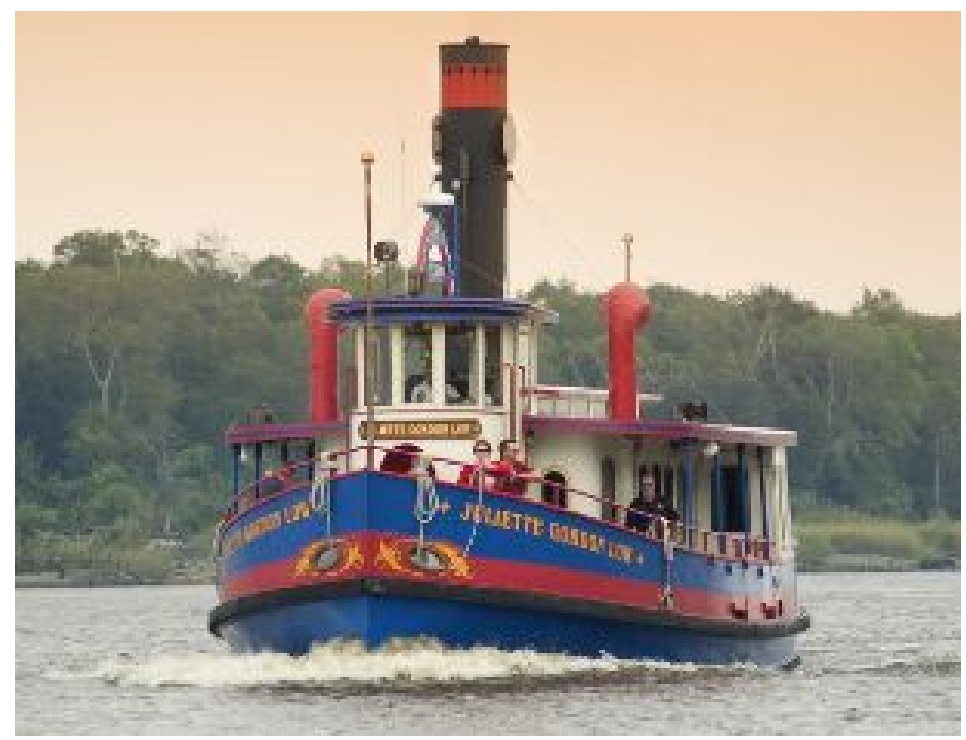


The year 2008 AADT on the two bridges combined was 172,000, over a bridge length (each way) of $2.54 \mathrm{mi}(4.09 \mathrm{~km})$ [21]. The 2008 vehicle-mi were 159,649,640 (256,931,522 vehicle-km). Although one of the bridge spans features two, reversible high-occupancy vehicle lanes, data on their use were not available. An average vehicle occupancy of 1.6 was assumed, based on data from the National Household Travel Survey [22]. Thus, the 2008 auto passenger-mi on the bridge were 255,439,424 (411,090,693 passenger-km). The New Orleans Regional Transit Authority (NORTA) was operating five routes across the Greater New Orleans Bridges, with a total of 41 round trips daily, plus an additional 13 round trips on the weekends [23]. Although patronage data on the five routes were not available, the average occupancy of all NORTA buses in 2008 was 7.23 persons. Given that 81,722 vehicle-mi $(131,519$ vehicle-km) were covered by the five routes across the bridge in 2008 , the passenger-mi were 590,691 (950,627 passenger-km). The daily volume of buses was only a small fraction of the AADT. A snapshot of the bridges is shown in Figure 4.

The Crescent City Connection ferries consumed 375,800 gal (1,422,443 L) of diesel fuel in 2008. Using Louisiana's year 2008 motor vehicle registrations distribution of $48.5 \%$ passenger cars and $51.5 \%$ light trucks, and the rates discussed above, the estimated average fuel efficiency for motor vehicles crossing the bridge was 20.28 MPG (8.62 km/L). The 62,780,000 motor vehicles crossing the Greater New Orleans Bridges, therefore, burned 7,872,270 gal (29,799,691 L) of gasoline in 2008. The NORTA buses burned 19,980 gal (75,633 L) of diesel and 4750 gal $(17,981 \mathrm{~L})$ of biodiesel fuel in crossing the bridge in 2008. The passenger-MPG of the ferries was $2.61(1.11 \mathrm{~km} / \mathrm{L})$, in comparison to that of the NORTA buses (24.18) and private motor vehicles (32.45). Similarly, the BTU per passenger-mi for the ferries, at 49.558.1, was substantially greater than that of the buses (5355.5) or other motor vehicles (3513.3). The data are summarized in Table 4; one of the Canal Street ferry boats is shown in Figure 5.

Table 4. Year 2008 Crescent City Connection and New Orleans Regional Transit Authority Statistics.

\begin{tabular}{lccccc}
\hline \multicolumn{1}{c}{ Mode } & Route & Passenger-Mi & $\begin{array}{c}\text { Fuel Consumed } \\
\text { (gal) }\end{array}$ & $\begin{array}{c}\text { Passenger } \\
\text { MPG }\end{array}$ & BTU/Pass-Mi \\
\hline $\begin{array}{l}\text { Crescent City } \\
\begin{array}{l}\text { Connection } \\
\text { (ferries) }\end{array}\end{array}$ & $0.38 \mathrm{mi}$ & 982,000 & 375,800 & 2.61 & $49,558.1$ \\
$\begin{array}{l}\text { Crescent City } \\
\begin{array}{l}\text { Connection } \\
\text { (bridges) }\end{array}\end{array}$ & $2.54 \mathrm{mi}$ & $255,439,424$ & $7,872,270$ & 32.45 & 3513.3 \\
$\begin{array}{l}\text { New Orleans } \\
\text { Regional Transit } \\
\text { Authority (bus) }\end{array}$ & $2.54 \mathrm{mi}$ & 590,691 & & & \\
\hline \multicolumn{1}{r}{ Ferries: diesel; bridge (motor vehicles): gasoline; buses: diesel (80\%) and biodiesel (20\%). }
\end{tabular}


Figure 4. Greater New Orleans Bridges (Crescent City Connection) [24].

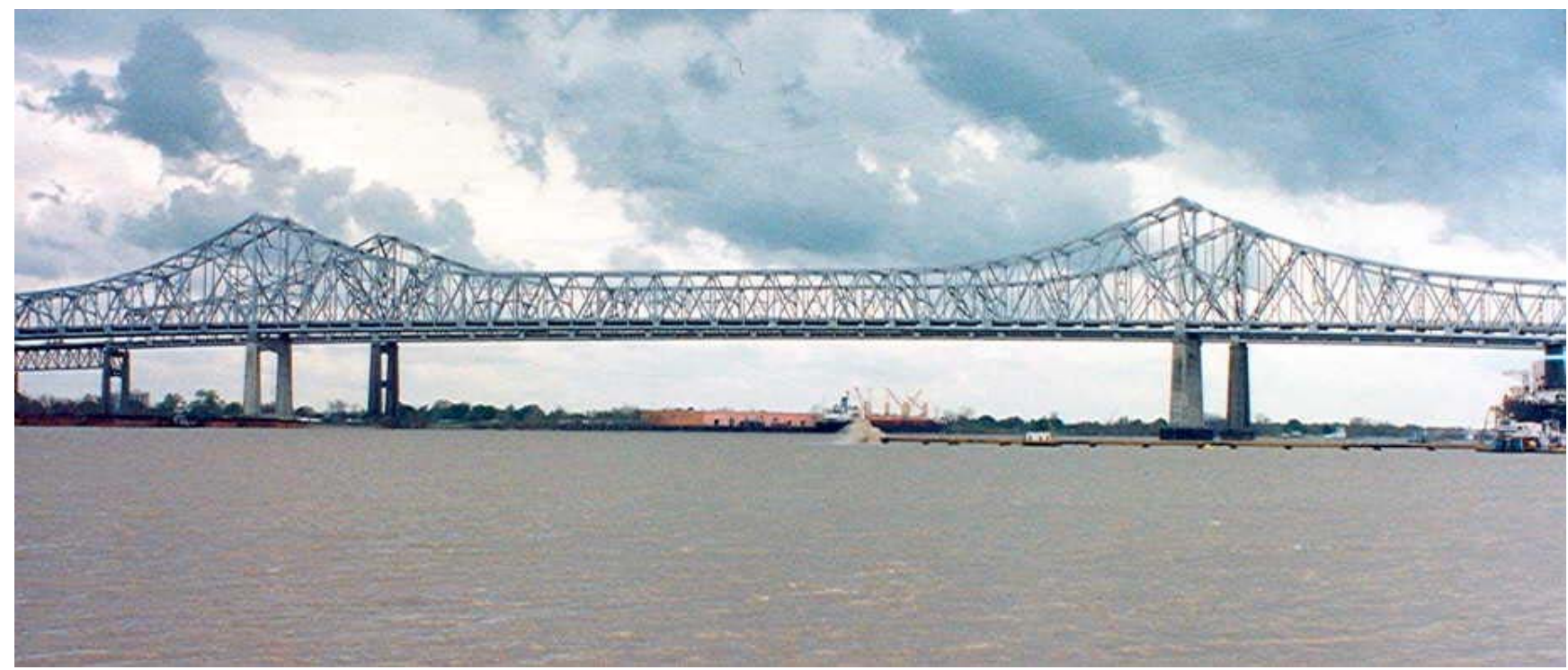

Figure 5. Canal Street Ferry [25].

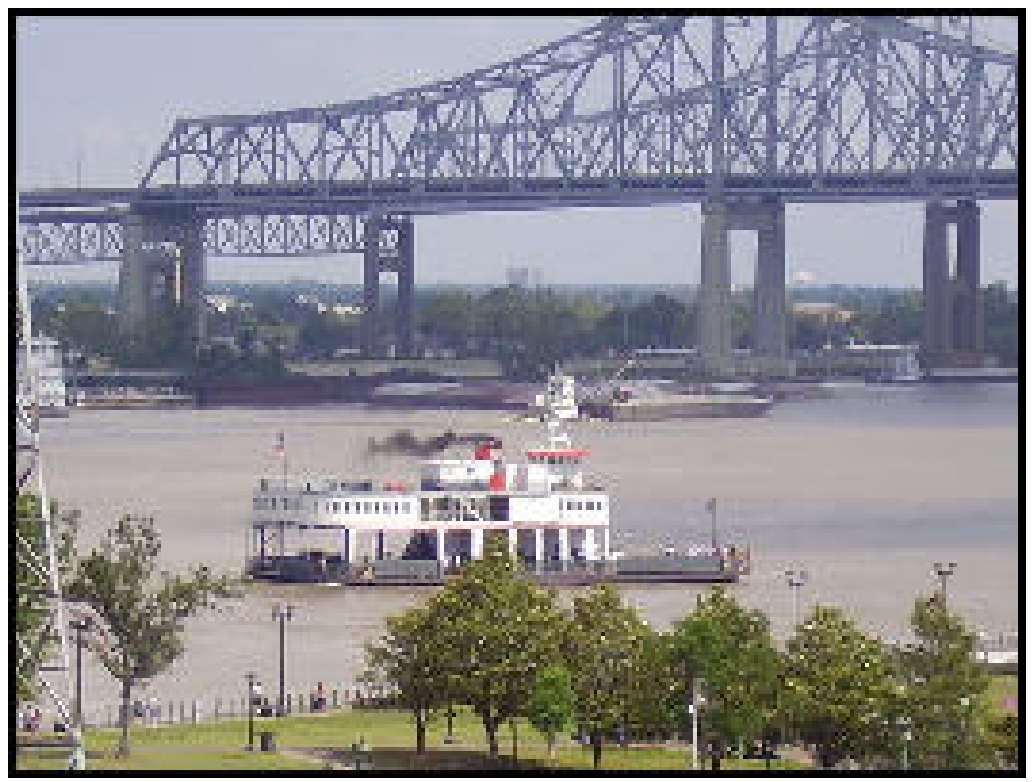

\section{Ferry Boat Fuel Consumption Model}

Before attempting to generalize the energy consumption results, it was useful to estimate a model of ferry boat fuel consumption. The data in Table 1 suggest that fuel efficiency is inversely proportional to vessel size. Also, as suggested earlier, fuel efficiency is related to water current, wind, and operating speed. Environmental conditions data were not available for this study, but the typical average operating speeds of the eight systems listed in Table 1 ranged from $7 \mathrm{mph}(11.3 \mathrm{~km} / \mathrm{h})$ for the Crescent City Connection, to $26.4 \mathrm{mph}(42.5 \mathrm{~km} / \mathrm{h})$ for the Golden Gate Ferries. An equation was estimated using data from the eight ferry systems. With so few data points, it was not possible to validate the model, but the sum of the squares of the residuals about the observed MPG values was 0.06165 . 


$$
\mathrm{MPG}=\left(10,600 / \mathrm{CAP}^{2.2}\right)+\left(10 / \mathrm{SPEED}^{2}\right)
$$

where:

MPG = ferry system fuel efficiency (miles per gallon);

$\mathrm{CAP}=$ passenger capacity of a vessel, and

SPEED = typical vessel operating speed $(\mathrm{mph})$.

The equation estimates the fuel efficiencies of the Maritime Transportation Authority, Port Imperial Ferry, Savannah Belle Ferries, and Washington State Ferries reasonably well. The equation underestimates the fuel efficiencies of Casco Bay Island Transit, Golden Gate Ferries, and Staten Island Ferry, and overestimates that of the Crescent City Connection. Additional variables on environmental conditions, and on specific aspects of the vessels, may be needed to improve the estimates. Also, many of the systems have a variety of vessel capacities and operating speeds, such that fuel efficiency varies among the vessels. This level of detail is not represented in the equation.

\section{Application of the Results}

The analysis was extended to two cases in which there is a ferry boat service, but no bridge, at a water crossing. The first case, near the San Francisco Bay area in California, is a Sacramento River crossing between the Solano County "mainland" and Ryer Island in Sacramento County, closing a gap in SR 84. The second case, in southeastern Utah, is a crossing of Lake Powell between Bullfrog Marina and Hall's Crossing, closing a gap in SR 276. The Ryer Island crossing has a length of $0.16 \mathrm{mi}$ (0.26 km), and served 230 vehicles per day in 2008 [9]. The Ryer Island Ferry, operated by the California Department of Transportation, can carry up to six to eight vehicles per trip. The equivalent passenger capacity is about 49. The ferry runs “on demand," implying that up to 230 trips per day could be made (one per vehicle), which would be the worst case for fuel consumption. The crossing is made in $3 \mathrm{~min}$, including docking, suggesting an average speed of about $4 \mathrm{mph}(6.4 \mathrm{~km} / \mathrm{h})$ [26]. Using Equation (2), the Ryer Island Ferry's fuel efficiency was about 2.65 MPG (1.13 km/L). In making 230 crossings per day, or 83,950 per year, covering 13,432 $\mathrm{mi}(21,617 \mathrm{~km})$, the ferry burned about 5069 gal $(19,188 \mathrm{~L})$ of diesel fuel. In comparison, if a bridge were available to the 230 daily vehicles that use the ferry, then just 645 gal (2443 L) of gasoline would be consumed, assuming an average fuel efficiency of 20.81 MPG (as discussed in section 5, above). For the Ryer Island Ferry to have increased fuel efficiency, one strategy would be to reduce the number of trips. If the boat made just 30 trips per day, for example, then the fuel consumption would be approximately equal to that consumed by the vehicles on a hypothetical bridge crossing. Motorists might be faced with a ferry boat wait time of up to one hour, however, with the less frequent service.

The Charles Hall Ferry, operated by Aramark (private company), crosses Lake Powell within the Glen Canyon National Recreation Area between Bullfrog Marina and Hall's Crossing in Utah, closing a gap of $3.1 \mathrm{mi}(5.0 \mathrm{~km})$. A one-way trip takes $25 \mathrm{~min}$, at an average cruising speed of about $7 \mathrm{mph}$ $(11.3 \mathrm{~km} / \mathrm{h})$. The ferry operates from April until November, making between four and five round trips per day [27]. In 2010, the ferry was scheduled to make 1,846 one-way trips across the lake, accumulating $5723 \mathrm{mi}(9210 \mathrm{~km})$ [28]. Each of the two boats available for the service has a passenger capacity of 149 [16]. Using Equation (2), the Charles Hall Ferry's fuel efficiency was about 0.38 MPG $(0.16 \mathrm{~km} / \mathrm{L})$. The two boats were burning a total of about 15,075 gal $(57,066 \mathrm{~L})$ of diesel fuel in 2010, 
based on the year's schedule. In comparison, the 300 daily vehicles that use the ferry [29] would burn 9149 gal (34,633 L) of gasoline on a bridge over Lake Powell, assuming an average fuel efficiency (in Utah) of 20.33 MPG (8.64 km/L), and 200 days of use per year. (In reality, if there was a bridge across Lake Powell, it might be open all year). One strategy for improving the fuel usage of the ferry would be to reduce the number of trips; if the number were cut by about $40 \%$, then the fuel consumption would be roughly equivalent to that of a hypothetical bridge. One strategy for improving the fuel efficiency of the ferry would be to use a smaller boat; according to Equation (2), a 75 -passenger boat would consume about $60 \%$ less fuel than the current, 149-passenger vessel.

\section{Generalization of the Results}

The overall finding is that ferry boats are less fuel efficient than motor vehicles on bridges, and that the total fuel consumption of a ferry can greatly exceed that of motor vehicles, depending on the number of trips made, vessel operating speed, passenger capacity, and other factors that are not represented in Equation (2). Using the variables that are represented, the relationship can be described as follows:

$$
\mathrm{OCC}_{\mathrm{mv}} \times \mathrm{MPG}_{\mathrm{mv}}=\mathrm{OCC}_{\mathrm{ferry}} \times \mathrm{MPG}_{\text {ferry }}
$$

where:

$\mathrm{OCC}_{\mathrm{mv}}, \mathrm{OCC}_{\mathrm{ferry}}=$ average passenger occupancy of motor vehicles and ferries, respectively, and

$\mathrm{MPG}_{\mathrm{mv}}, \mathrm{MPG}_{\mathrm{ferry}}=\mathrm{MPG}$ of motor vehicles and ferries, respectively.

Equation (3) illustrates that the only way to offset the lower MPG of the ferry, relative to that of the motor vehicle, is to have a greater occupancy. Ferry boats are, of course, much larger than motor vehicles, but this efficiency is negated if frequent, low-volume trips are made. In any given crossing setting, there are one or more combinations of vessel size, operating size, passenger demand, and trip frequency that would equate the fuel consumption of a ferry boat with that of motor vehicles on an adjacent highway bridge. The large number of variables is such that comparisons must be made on a case-by-case basis, as was done in this paper. Further, the frequency with which passengers are served must be considered, since long gaps between crossings may not be tolerated. Outside of finding the right combination of variables, which may not exist in a given setting, the only other option would be to use a fuel-efficient vessel. The examination of ferry boat engineering, as it pertains to fuel economy, was beyond the scope of this study.

\section{Conclusion: Policy Considerations}

Regulations of marine vessel engines have targeted their emissions rather than their fuel economy. Since 1999, EPA rules have progressively reduced sulfur, particulate matter and nitrogen oxide emissions from Categories 1, 2 and 3 marine engines. (Category 3 engines are generally found on large, ocean-going vessels, while ferry boat engines are either Category 1 or 2). Some of the legislation has been modeled after similar rules for highway engines. An equivalent to the corporate average fuel economy (CAFÉ) standards for highway vehicles does not exist for marine vessels, however. Although models of emissions and fuel consumption have been developed (e.g., [30]), Equation (1) illustrates that fuel consumption is independent of emissions. Further, emission masses can vary widely between 
vehicles or vessels, such that the treatment of emissions as an independent variable, with fuel consumption as an independent variable, is likely to yield imprecise results. It is recognized that greenhouse gas emissions can be reduced with decreased fossil fuel consumption [31], but fuel efficiency otherwise requires separate standards. Since the passenger-miles accumulated by ferry boats in 2007 represented less than $2 \%$ of all public transit travel, and less than $0.01 \%$ of all travel, it can be argued that the development and implementation of fuel economy standards for this mode is not a high priority. Increased fuel efficiency among ferries would, however, serve to enhance the role of waterborne transit as a sustainable form of public transport. Further, improved ferry boat fuel efficiency may make this form of transport a more desirable alternative at crossings where bridges are congested, structurally deficient, or infeasible.

\section{References}

1. Bradley, M.J. Comparison of Energy Use and $\mathrm{CO}_{2}$ Emissions from Different Transportation Modes; American Bus Association: Washington, DC, USA, 2007.

2. Perry, E. Economic Dimensions of Ferry Operations in Missouri, Kentucky and Tennessee: The Dorena-Hickman Ferry; Missouri Department of Transportation: Jefferson City, MO, USA, 2008.

3. Analysis of Commercial Marine Vessels Emissions and Fuel Consumption Data. Office of Transportation and Air Quality, Environmental Protection Agency: Washington, DC, 2000.

4. Emission Facts: Average Annual Emissions and Fuel Consumption for Gasoline-Fueled Passenger Cars and Light Trucks. Office of Transportation and Air Quality, Environmental Protection Agency: Washington, DC, USA, 2005.

5. Evans, C.; Cheah, L.; Bandivadekar, A.; Heywood, J. Getting More Miles per Gallon. Available online: http://www.issues.org/25.2/index.html (accessed on 15 October 2010).

6. RITA. National Census of Ferry Operators; Available online: http://www.transtats.bts.gov/ Tables.asp?DB_ID=616\&DB_Name=National\%20Census\%20of\%20Ferry\%20Operators\&DB_S hort_Name=Ferry\%20Census (accessed on 24 January 2010).

7. Federal Transit Administration. National Transit Database. Available online: http://www. ntdprogram.gov/ntdprogram/data.htm (accessed on 24 January 2011).

8. Downing, R.; Kupersmith, C.G. Monthly Report on Bridge Traffic, Transit Ridership Trends, and Transit Service Performance; Golden Gate Bridge, Highway and Transportation District: San Francisco, CA, USA, 2010.

9. Traffic Volumes-2008; Traffic Data Branch, California Department of Transportation: Sacramento, CA, USA, 2009.

10. Golden Gate Transit Bus Schedules. Available online: http:/goldengatetransit.org/schedules/ pages/Bus-Schedules.php (accessed on 24 January 2011).

11. Comprehensive Annual Financial Report for the Fiscal Years Ended June 30, 2008 and 2007; Golden Gate Bridge, Highway and Transportation District, Accounting Department, Office of the Auditor-Controller: San Francisco, CA, USA, 2009.

12. State Transportation Statistics 2009; Bureau of Transportation Statistics, Research and Innovative Technologies Administration, U.S. Department of Transportation: Washington, DC, USA, 2010. 
13. Purvis, C.L. Changes in Regional Travel Characteristics and Travel Time Expenditures in the San Francisco Bay Area: 1960-1990; In Transportation Research Record 1466; Transportation Research Board, National Research Council: Washington, DC, USA, 1994; pp. 99-109.

14. MTC. Travel Forecasting Assumptions '98 Summary-1998 Update of Regional Transportation Plan; Planning Section, Metropolitan Transportation Commission: Oakland, CA, USA, 1998; Available online: http://www.mtc.ca.gov/maps_and_data/datamart/forecast/assume98.htm (accessed on 27 September 2010).

15. Contemporary Photos of the Golden Gate Bridge; Available online: http://www.goldengatebridge. org/photos/current.php (accessed on 1 October 2010).

16. Photos-The Current Fleet of Vessels Providing Ferry Service across the San Francisco Bay. Available online: http://www.goldengateferry.org/researchlibrary/photos.php (accessed on 1 October 2010).

17. Georgia Department of Transportation. Georgia's State Traffic and Report Statistics; Available online: http://www.dot.ga.gov/statistics/stars/Pages/ChathamTraffic.aspx (accessed on 27 September 2010).

18. Annual Vehicle Occupancy Monitoring Program Report: Jan. 1, 2003-Dec. 31, 2003; Traffic Information Division, Nevada Department of Transportation: Carson City, NV, USA, 2004.

19. U.S. Highway 17 Southbound. Available online: http://www.southeastroads.com/us-017b_ga.html (accessed on 1 October 2010).

20. CAT. Fare-Free Savannah Belles Ferries. Available online: http:/catchacat.org/content/ FareFreeServices/SavannahBellesFerry.aspx (accessed on 24 January 2011).

21. Jurisdictional Scan of Traffic Management during Incidents on Bridges; Engineering Branch, BC Ministry of Transportation and Infrastructure: Victoria, Canada, 2008.

22. PITA. NHTS: Highlights of the 2001 National Household Travel Survey; Bureau of Transportation Statistics, U.S. Department of Transportation: Washington, DC, USA, 2003.

23. System Map—Regional Transit Authority. Available online: http://www.norta.com/?page=system (accessed on 24 January 2011).

24. Crescent City Connection. Available online: http://en.wikipedia.org/wiki/Crescent_City_Connection (accessed on 1 October 2010).

25. Expanded Gretna-Canal Street ferry service begins Monday. Available online: http://media.nola. com/news_impact/photo/29wbferry5jp-958ad74377a6056e_large.jpg (accessed on 1 September 2010).

26. Suard, N. History of Real McCoy and J-Mac Ferries Serving Ryer Island; Available online: http://www.snugharbor.net/ferryhistory.htm (accessed on 14 October 2010).

27. Ferry Service-Lake Powell Resorts and Marinas. Available online: www.lakepowell.com/ferryservice.aspx (accessed on 15 October 2010).

28. Halls Ferry-2010 Rates \& Schedule; Utah Department of Transportation: Salt Lake City, UT, USA, 2010; Available online: www.udot.utah.gov/main/uconowner.gf?n=13516628792329122 (accessed on 15 October 2010).

29. Traffic on Utah Highways 2009; Traffic Analysis Section, Systems Planning and Programming Division, Utah Department of Transportation: Salt Lake City, UT, USA, 2010. 
30. Leung, D.Y.C.; Williams, D.J. Modelling of Motor Vehicle Fuel Consumption and Emissions Using a Power-Based Model. Environ. Monit. Assess. 2000, 65, 21-29.

31. Shaheen, S.A.; Lipman, T.E. Reducing Greenhouse Emissions and Fuel Consumption. IATSS Res. 2007, 31, 6-20.

(C) 2011 by the authors; licensee MDPI, Basel, Switzerland. This article is an open access article distributed under the terms and conditions of the Creative Commons Attribution license (http://creativecommons.org/licenses/by/3.0/). 